\title{
Knowledge for Whom? Inviting Students to Establish an Audience for Knowledge and to Shape Knowledge Construction Activities in a Biology Course
}

\author{
Heesoo $\mathrm{Ha}^{1}$ (D) \\ Accepted: 6 November 2021 / Published online: 22 November 2021 \\ (c) The Author(s), under exclusive licence to Springer Nature B.V. 2021
}

\begin{abstract}
One main obstacle for instructors in inviting students to design knowledge construction is the tension between prioritizing students' ideas and maintaining the scientific validity of the activity. In this study, as a way of supporting students in shaping their own knowledge construction, the establishment of an audience for knowledge was enacted in a knowledge construction activity in a biology course. Applying the multiple case study method, this study aimed to explore whether and how the establishment of an audience for knowledge can support students' shaping of knowledge construction that is both scientifically valid and meaningful to students. The recordings of 26 student discussions and student-produced artifacts were analyzed as the main data sources. Student-created audiences and the epistemic features of knowledge construction processes were identified, and how the establishment of the audience did or did not support students' knowledge construction was inferred. The analysis revealed that the students first explicated their epistemic goals by creating audiences as persons who hold students' uncertainties and then designed processes to resolve these uncertainties. This indicates that the created audiences could explicate the object orientation of student activities, serving as the central axis in the students' subsequent shaping of the process to construct knowledge that is meaningful to themselves. However, the activity had limited value in supporting the students' plans for scientifically valid knowledge construction. The instructional strategies that are needed to support students in maintaining scientifically valid plans in practice are discussed. This study has pedagogical implications for the development of instructional strategies to support students' epistemic agency as they engage in shaping their own knowledge construction.
\end{abstract}

Keywords Epistemic agency $\cdot$ Audience for knowledge $\cdot$ Epistemic goal $\cdot$ Knowledge construction

Heesoo Ha

snudunoy717@snu.ac.kr

1 Center for Educational Research, Seoul National University, 1, Gwanak-gu, Seoul, Republic of Korea 08826 


\section{Introduction}

Facilitating students' active participation in knowledge construction in the science classroom has been a central issue in science education. This issue has been further focalized by the attention given to scientific practices in the Next Generation Science Standards. Within this movement, as focusing on students' practices for learning in the science classroom, students' epistemic agency, which can be described as their capacity to shape knowledge and knowledge construction activities in the science classroom, has been discussed (e.g., Miller et al., 2018).

Studies (e.g., Miller et al., 2018; Stroupe et al., 2018) have identified students' epistemic agency in their activation of cognitive and sociocultural resources and their contribution to the development of knowledge. Although the focus has primarily been on the activation of resources, another important aspect of agency is an agent's pursuits of their own purposes. "Actions" in an activity are organized and enacted according to an object, and object-orientedness provides the actions' meaning (Engeström, 1987). Consistent with this discussion, scientific practices refer to a set of performances and interactions that are accepted in scientific communities to achieve the goal of better explaining the natural world (Ford, 2015). This notion indicates that to support students in their positioning as epistemic agents, their recognition of objects for their actions matters. When teachers design classroom activities to facilitate students' epistemic agency, the objects for students' practices are often predetermined (Reiser et al., 2017). Students are expected to be motivated by a question that a teacher raises, align their objects with those designated in the activity, and activate their resources to achieve the objects. However, discussion is lacking on whether students are motivated in this type of curriculum and how students can shape knowledgeconstructing activities in the science classroom. To support students in being positioned as epistemic agents, more discussion is needed on instructional strategies that can support students in contriving objects of knowledge construction and in shaping their own activities in the science classroom.

There are many concerns that surround inviting students to contrive objects of knowledge construction. A main concern is whether students can construct scientifically meaningful activities (Stroupe et al., 2018). Looking for the key aspect of classroom activities that can support students' construction of activities, the current study attended to the audience for knowledge. An audience for knowledge refers to those for whom the knowledge is produced, which means that the audience is the person to whom the knowledge should be persuasive. The existing studies about an audience for knowledge (e.g., Berland et al., 2016) indicate that in evaluation-focused classrooms, students learn knowledge to achieve higher grades, and the audience for knowledge that students produce is considered to be teachers. In contrast, in classrooms that enact sense-making activities that explore predetermined questions, students are expected to be the audience for the knowledge. In the scientific community, scientists produce knowledge in particular ways so that the knowledge can be persuasive to other scientists, but the audience is not limited to only scientists (Myers, 2003). Public members in a variety of social sectors can participate in the discussion and influence scientific development, which provides various rationales for scientific research (Myers, 2003). This indicates that audiences of scientific knowledge are key sources that produce epistemic goals for scientists to expand knowledge about the natural world. Reflecting this aspect of scientific work indicates the potential for an explicit establishment of audiences other than students as a possible method of instructional design that could motivate students to produce evidence-based knowledge. 
Then, when students are invited to do so, can the establishment of an audience support students' shaping of knowledge construction? By answering this question, this study aims to contribute to the development of instructional strategies that invite students to construct epistemic activities and form motivations for their own activities in science classrooms. The specific research questions of this study are as follows: When students are asked to establish an audience for knowledge, (a) (how) does the establishment of an audience support knowledge construction that is meaningful to the students? (b) (How) Does the establishment of an audience support scientifically meaningful knowledge construction?

\section{Background of the Study}

This study draws on the construct of epistemic agency (Miller et al., 2018) and views one primary goal of science education as supporting students' positioning as agents who shape their own knowledge and knowledge construction activity. In addition, by drawing on the practical epistemology perspective (Berland et al., 2016; Sandoval, 2005), this study views that students enact their epistemic ideas of their own knowledge construction processes and that students' epistemic goals and epistemic ideas can be inferred from their participation and discourse to construct knowledge.

\section{Epistemic Agency in the Science Classroom}

Shifting the goal of science education from learning content knowledge to making sense of natural phenomena through participation in practices has been widely advocated (e.g., National Research Council, 2012). In a classroom with such a goal, students are expected to position themselves as epistemic agents who construct valid knowledge to figure out the natural world through practices that reflect scientific practices (González-Howard \& McNeill, 2020). Epistemic agency is defined as "students being positioned with, perceiving, and acting on, opportunities to shape the knowledge building work in their classroom community" (Miller et al., 2018, p. 1058) and is described as being opposed to the passive recipients of information in the traditional classroom. To facilitate students' epistemic agency in the science classroom, studies have discussed that instructional support is needed for students to adapt scientific practices (González-Howard \& McNeill, 2020), engage in knowledge construction, and build the knowledge construction process (Ko \& Krist, 2019; Miller et al., 2018; Reiser et al., 2017).

This study aims to contribute to the development of pedagogies to support students' epistemic agency by focusing on the object-orientedness of epistemic agents' activation of resources in knowledge construction activities. The construct of epistemic agency that this study draws on is based on the sociocultural literature that places human actions within social structures and conceptualizes agency as the actors' ability to activate their resources to achieve their goals (Engeström, 1987; Holland et al., 1998). In brief, Holland et al. (1998) developed the notion of agency in relation to agents' identities and described agents as activating their resources with the goal of constructing positive selves through their activities. Engeström (1987) more explicitly delineated agents' purposes for their actions. He suggested that the "object-orientedness of action became the key to understanding human psyche" and that objects are "carriers of motives" (pp. xiv, xvi). Consistent with this discussion, the goal of developing explanations of the natural world is central to characterizing a set of performances and interactions as "scientific" practices (Ford, 2015). An 
implication that can be drawn from this line of literature is that inviting students to contrive epistemic goals for their own knowledge construction can be an instructional strategy to support students' epistemic agency in the science classroom. However, inviting students to contrive epistemic goals and shape knowledge construction is not an easy choice for instructors because of tensions in designing curricula positioned between the appropriation of epistemic features of scientific knowledge construction and prioritizing students' ideas in shaping the knowledge construction process (Stroupe et al., 2018). This indicates that more discussions on and development of instructional strategies are needed in science education fields to support students' participation in shaping epistemic activities.

\section{Meaningfulness of Epistemic Goals to the Scientific Community and the Classroom Community}

The tensions in designing curricula as described in Stroupe et al. (2018) indicate that support for students' positioning as epistemic agents in the science classroom entails two expectations. One is for students to be able to shape knowledge construction around the epistemic goals that they value. Another expectation is for these goals to reflect scientific practices, which refers to developing evidence-based explanations of the natural world. In Berland et al. (2016), these two expectations were discussed as epistemic goals that "hold the actions together as a sensible practice" (p. 1085) and that are meaningful to the classroom community and scientific community, respectively.

Students' epistemic goals are enacted in their knowledge construction by using their epistemic ideas, which refer to students' ideas about how and what kind of knowledge is justified and evaluated in the science classroom (Berland et al., 2016; Sandoval, 2005). These ideas are multifaceted, encompassing aspects, such as the nature of knowledge, and are enacted in students' practices (Berland et al., 2016; Hammer \& Elby, 2002). Among the various aspects to which epistemic ideas belong, the current study especially focuses on the audience for knowledge aspects. The epistemic ideas of this concern are described as answers to the question, "Who will use our knowledge products and how?" (Berland et al., 2016, p. 1092). Although students are expected to perceive themselves as audiences and knowledge producers in sense-making activities, to the best of my knowledge, this has not been empirically examined. This study aims to explore not only how students posit the audiences for the knowledge that they produce but also whether and how students can meaningfully shape knowledge construction in both senses when a curriculum designed with students' establishment of audiences is enacted in the science classroom.

\section{Method}

This study takes the qualitative multiple case study approach (Merriam, 1998) to explore the processes and outcomes of students' activities and identify general patterns regarding whether and how the establishment of an audience for knowledge can support students' shaping of knowledge construction.

\section{Participants and Context}

The data came from a biology course for non-biology major students offered at a college in South Korea. There was no requirement to enroll in the course, and the course covered 
core concepts in biology. The author of this study worked as an instructor of this course. Twenty-eight students enrolled in the course were divided into 12 groups. However, only 11 groups (26 students) were analyzed in this study because the data collected in one group were too limited for analysis. The students were informed of the research, and only the work of the students who agreed that their data could be presented is described in this study.

Based on the previous literature's discussion on the necessity of instructional support for students to understand scientific practices (González-Howard \& McNeill, 2020), the course included three aspects to support students' understanding of scientific knowledge construction as follows: (a) Students were introduced to scientific inquiry, as an idealized but representative depiction of scientists' knowledge construction processes (Duschl \& Grandy, 2008) in the earlier lessons of the course. Representative methods and processes of scientific inquiry, such as deductive and inductive scientific inquiry and scientific modeling, were explained with exemplary cases. (b) Scientific argumentation was introduced to explain that classroom discussions in this course would evaluate and develop students' knowledge products. (c) An example of scientific knowledge for a specific group of people was described-research about lung cancer in female smokers (e.g., Haugen, 2002).

The knowledge construction activity was designed to provide a context for students to contrive an audience for knowledge for their subsequent knowledge construction, and the literature about opening up the curricula (Ko \& Krist, 2019; Miller et al., 2018; Reiser et al., 2017) was referred to support the students' epistemic agency in the activity. The activity included three phases carried out in one semester. In the first phase, the students created audiences for whom they would construct scientific knowledge. It was explained that the audience could be specified through various features, such as demographic information, behaviors, preferences, and life cycles. Most importantly, the students were guided to specify the problems that the created audiences would have and the research questions that scientific knowledge could be used to solve. For the content of the activity, the students were encouraged to specify research questions relevant to concepts in any fields of biology and, instead, focus on contriving the research questions for the created audiences. In the second activity phase, the students designed methods of constructing knowledge, including data collection and evidence-based knowledge construction for the audiences. By guiding the students to construct knowledge that the audiences that they created can accept and use, it was expected that the students would use their descriptions of the audiences as criteria to evaluate and develop their research methods. In the last phase, the students conducted the research as they designed it in the second phase and produced knowledge in the form that they thought was suitable for the audiences.

The students worked in groups of two to three people and held discussions via Zoom, phone, and Slack. At the end of each phase, whole-class discussions were held, and these helped the students refine their audiences and methods of knowledge construction and share their work. There was also a mid-phase whole-class discussion during the first phase to help the students refine their understandings of what an audience is-the person to whom the students deliver the knowledge, not the subject to investigate. Based on this discussion, the students refined the audiences and epistemic goals that they had created.

\section{Data Collection and Analysis}

To collect qualitative data, the group and whole-class discussions were all recorded and transcribed. The student-produced artifacts during the activities, the students' reflective 
reviews of their activities, and their reports on the process of their activities were collected at the end of the semester. During the data analysis, the transcriptions of the students' group discussions and the artifacts produced in each phase were used as primary data, and other data were used as auxiliary data.

The collected data were iteratively reviewed first to identify the audiences, the explored phenomena, and format the final knowledge product. The data and coding results were analyzed with the following questions to answer whether and how the audience establishment supported knowledge construction that is meaningful to students: Who did the students identify as the audiences? Why are the features of the audiences specified in the way that they are? (How) Are the specified features of the audiences reflected in the epistemic goals and the students' knowledge construction processes?

To answer whether and how the establishment of an audience supported knowledge construction that is scientifically meaningful, the students' epistemic ideas enacted in their activities were coded. The framework for identifying the epistemic ideas was first contrived based on the related literature (e.g., Berland et al., 2016; Hammer \& Elby, 2002) and modified during the analysis (Table 1). Specifically, epistemic ideas in aspects other than an audience for knowledge were identified in the following three aspects: (a) What type of answers does the knowledge product provide (nature of knowledge)? (b) What sources do the students use to justify their knowledge (source of knowledge)? (c) How is the knowledge justified (process of justification)? Because the students' initial plans for their activities were different from their actual practices, the epistemic ideas in their plans and practices were identified separately. The epistemic goals of the students' activities were identified based on the epistemic ideas and the students' descriptions of how the knowledge could help their audiences. The final codes are presented in Appendices Table 2 and 3.

After the coding of each case, the identified epistemic ideas in the nature of knowledge and process of justification aspects were compared with the scientific ones-to construct evidence-based mechanistic explanations of the natural world. Then, the general patterns across the cases regarding the research questions were identified. Especially regarding the second research question, changes in the enacted epistemic ideas in the second and third phases of the activities were identified and organized in a figure. The influence of establishing audiences on the students' shaping of scientifically meaningful knowledge construction was identified, and possible reasons were inferred for students' limited practices. The findings were organized with representative cases that could explain the general patterns.

To ensure the validity of the research, I discussed the data coding and analysis results with two other researchers and refined the parts on which they did not agree. One of the

Table 1 Framework for analyzing the epistemic ideas enacted in students' activities

\begin{tabular}{|c|c|}
\hline Epistemic aspects & Descriptive questions \\
\hline Audience of knowledge & Who will use the knowledge product and how? \\
\hline Nature of knowledge & $\begin{array}{l}\text { What kinds of answers are the knowledge product designed to provide? } \\
\text { What kinds of answers do the knowledge product provide? }\end{array}$ \\
\hline Source of knowledge & $\begin{array}{l}\text { What sources do students plan to use to justify their ideas? } \\
\text { What sources do students actually use to justify their ideas? }\end{array}$ \\
\hline Process of justification & $\begin{array}{l}\text { How are the ideas in the knowledge products designed to be justified? } \\
\text { How are the ideas justified during the students' activities? } \\
\text { How are the ideas in the knowledge products justified? }\end{array}$ \\
\hline
\end{tabular}


issues concerned the definition of scientific knowledge construction. This issue was raised because many groups used a "literature review" as their research method but limited their analysis to a repetition of previous studies, despite the emphasis on the construction of evidence-based knowledge in the activity. We reached an agreement to view all the students' activities as knowledge construction when they explicated knowledge claims or suggestions for audiences based on data or reasoning that the students contrived themselves. Another exemplary issue that was discussed was whether the establishment of an audience influenced the students' shaping of scientifically meaningful activities and whether there were other possible influential components of the course curricula on the students' activities. The analysis results were refined based on this discussion.

\section{Findings}

\section{Support for the Students' Shaping of Knowledge Construction That Is Meaningful to Them}

In most of the cases, the audiences that the students created reflected features of themselves or the people that they encountered in their daily lives. In addition, audiences were all described by stating the knowledge that the students wanted to know. Sometimes, the audiences were specified with situational descriptions that demanded knowledge-based suggestions on daily life matters, which foregrounded rationales for pursuing epistemic goals that were interrelatedly constructed. The described audiences' uncertainties and the rationales for holding these uncertainties were those held by the students; thus, the audience construction became the explication of the object that was meaningful to students.

This is explicitly shown in the process of audience creation in a group that said that they would construct knowledge for themselves as they "wondered how changes in human activities caused by the spread of COVID-19 influenced the environment." This group first set the explored phenomena as "the environment in South Korea that is influenced by the spread of COVID-19," because they interpreted the whom part in the knowledge for whom as indicating the subject to investigate (Fig. 1). Subsequently, the original epistemic goal constructed in this group was inferred as "to make sense of phenomena." In the second activity phase, the students' interpretation of the meaning of the audience shifted to the people to whom they wanted to deliver the knowledge that they produced, and the audience changed to themselves with a unifying characteristic: wondering how changes in human activities caused by the spread of COVID-19 influenced the environment. Although this group struggled to figure out what audience meant, the process of revising their audience showed that the students' epistemic goal of making sense of phenomena was explicated as audiences' questions and characteristics.

The rationales for constructing knowledge - the epistemic goals of their activitiesshown in the description of audiences served as the central axis in the students' subsequent shaping of knowledge construction activities. This is well shown in another group, where students Jen and Ryu aimed to make sense of people's different sensitivities to caffeine. Their descriptions of the audiences showed where this interest was derived from: Jen, who is sensitive to caffeine, and Ryu, who is insensitive to caffeine (Fig. 2). Furthermore, Jen and Ryu's features - such as their sex, age, and life patterns - and the symptoms that they experience when they drink coffee were described because the students thought that these factors could affect the mechanism underlying the symptoms that they experienced when 


\section{Translation}

[Personas in the first phase]

주제의 세부화

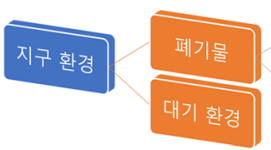

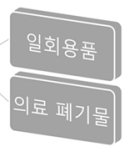

\section{Specification of the subject}

The earth environment

\section{Waste}

The air

environment

\section{Disposables}

Medical waste

[Personas in the second and third phases]

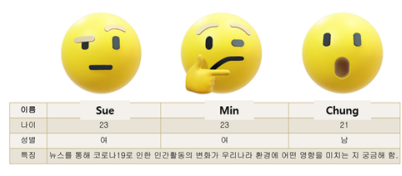

\begin{tabular}{cccc}
\hline Name & Sue & Min & Chung \\
\hline Age & 23 & 23 & 21 \\
Sex & Female & Female & Male
\end{tabular}

Characteristics Wonder how changes in human activities caused by COVID-19 influence the environment

Fig. 1 Audiences created by Chung, Min, and Sue

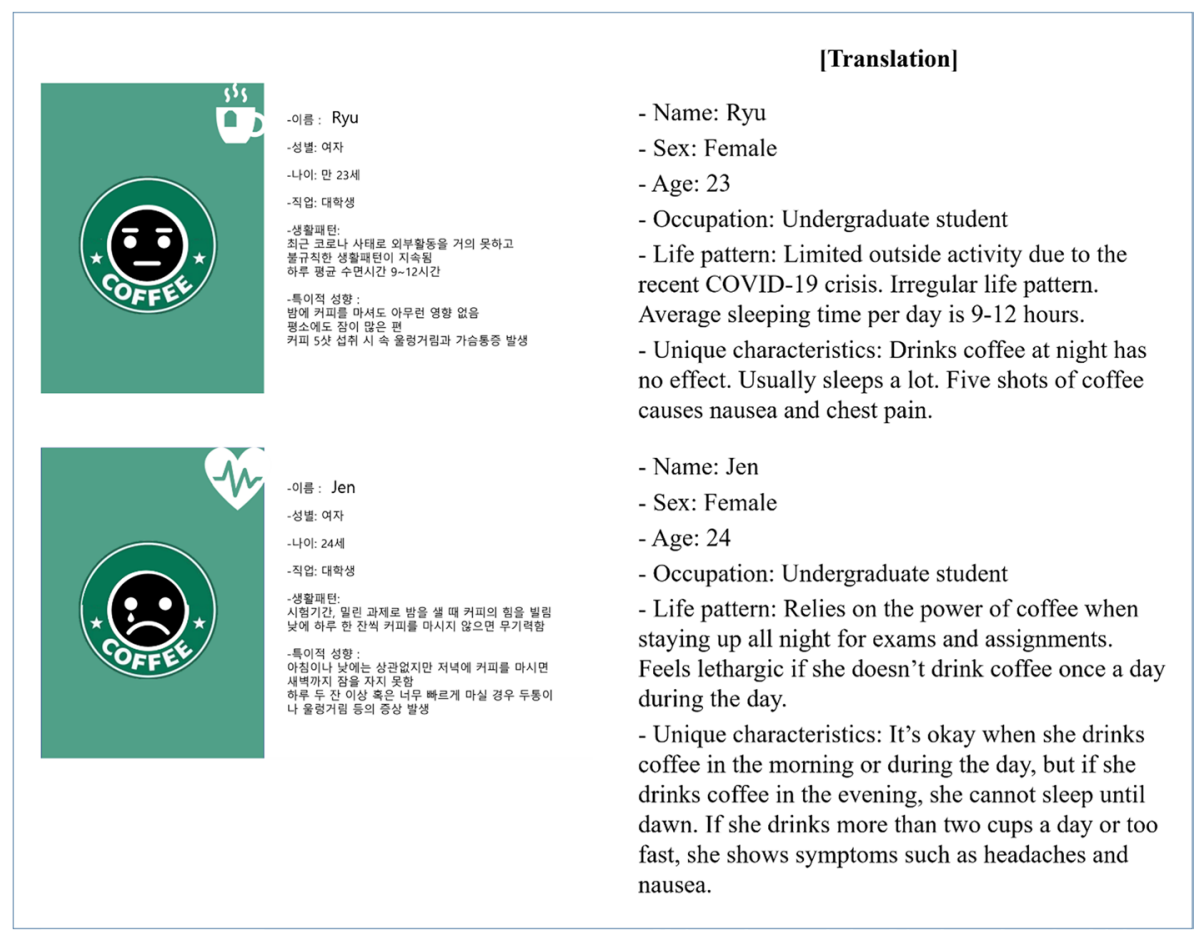

Fig. 2 Audiences created by Jen and Ryu 
they drank coffee. Representative evidence that supports this interpretation was the "table of contents" that Jen and Ryu constructed in the first phase (Fig. 3). The table of contents included the "speed of consuming coffee, psychological factors, differing response to caffeine due to different life patterns, and genetic factors" as the "body" of their report. The students created this table of contents so that they can "first construct a framework of [their] work and then fill in the contents [that elaborate each point]" to produce the mechanistic explanation of how the external factors that they specified as features of the audience changed their physiological status. As such, the students' personal features described in the audiences supported students to think of potentially mediating factors of sensitivity to caffeine. This case representatively shows that the students shaped their knowledge construction activities to achieve their epistemic goals, which are delineated from their description of the audiences who reflect the student' own uncertainties and features.

\section{Support for and Limitations of Supporting Students' Shaping of Scientifically Meaningful Knowledge Construction}

The analysis result of general patterns of changes in the enacted epistemic ideas in the second and third phases of the activities is shown in Fig. 4. The students planned to construct evidence-based mechanistic explanations, except for the groups that limited to bringing previous studies' works. However, many of the groups failed to enact their plans in their actual knowledge construction processes. In addition, in the nature of knowledge aspect, there were three groups that aimed to construct only descriptions phenomena. This section explains why these patterns emerged with the focus on the

\begin{tabular}{|c|c|}
\hline & [Translation] \\
\hline \multicolumn{2}{|l|}{ 지난 과제 4번 내용 } \\
\hline 2. 도입 & 2. Introduction \\
\hline $\begin{array}{l}\text { 2. 돕ㅂㅂ } \\
\text { 2. 1. 카페인이란? }\end{array}$ & 2.1 What is caffeine? \\
\hline 2. 2. 카페인의 중류와 든징 & 2.2 Types and characteristics of caffeine \\
\hline 2. 4. 작용부작용 & 2.3 Types and characteristics of coffee \\
\hline $\begin{array}{l}\text { 3. 선개 드 } \\
\text { 3. 1. 대생의 생활패턴 }\end{array}$ & 2.4 Effects and side effects \\
\hline 3. 2. 두 대상의 카페인에 대한 반응, 특징 및 특이사행 & 3. Development \\
\hline 4. 본론 & 3.1 Life patterns of the two personas \\
\hline $\begin{array}{l}\text { 4. 1. 마시는 슥도 } \\
\text { 4. 2. 심리적 요인 } \\
\text { 4. 3. 생핼 패틴에 따른 카페인에 대한 반응 앙상 } \\
\text { 4. 4. 유넌적 요인 }\end{array}$ & $\begin{array}{l}3.2 \text { The two personas' responses to caffeine and their unique } \\
\text { characteristics }\end{array}$ \\
\hline 5. 대안 탐구 및 제시 & 4. Main issues \\
\hline 5. 1. 커피의 종류를 바껵보기 & 4.1 Consumption speed \\
\hline \multirow[t]{7}{*}{ 5. 3. 생활습관 개선 } & 4.2 Psychological factors \\
\hline & 4.3 Different responses to caffeine due to different life patterns \\
\hline & \\
\hline & 5. Exploration and suggestion of alternatives \\
\hline & 5.1 Changing types of coffee \\
\hline & 5.2 Consuming caffeine with different beverages \\
\hline & 5.3 Improving life patterns \\
\hline
\end{tabular}

Fig. 3 Table of contents created by Jen and Ryu 


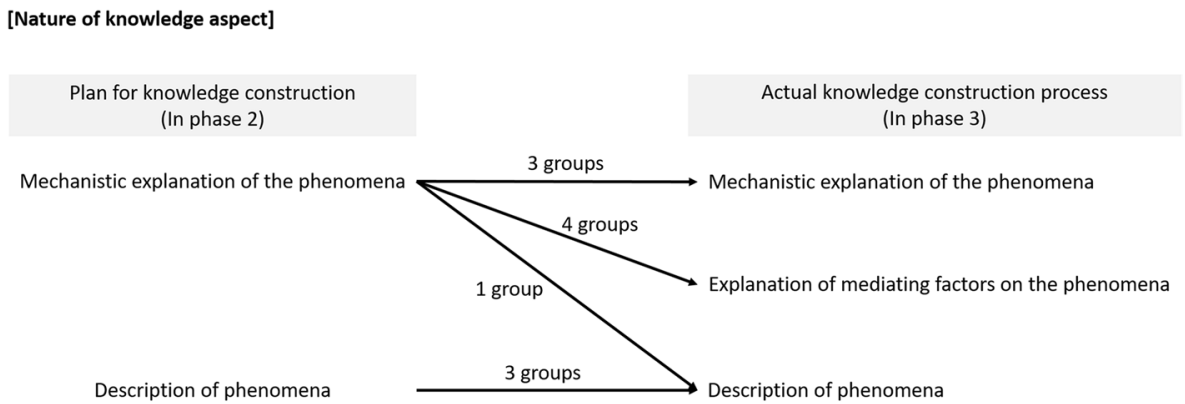

[Process of justification aspect]

Plan for knowledge construction (In phase 2)

Evidence-based justification
Actual knowledge construction process (In phase 3)

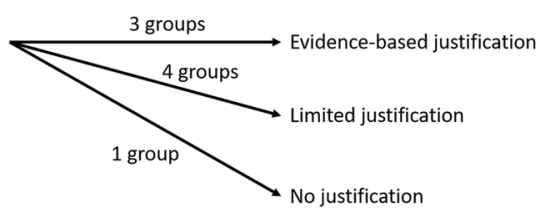

Reliance on authoritative sources

3 groups Reliance on authoritative sources

Fig. 4 General patterns of changes in the enacted epistemic ideas

audience construction supported or was limited in supporting students' shaping of scientifically meaningful knowledge construction.

The audience construction explicated the object-orientedness of students' activities and served as criteria for the students to shape the epistemic features of their activities in the nature of knowledge and process of justification aspects. Two features of the instructional context have contributed to the usage of the created audiences for shaping scientifically meaningful knowledge construction. One of them is the instructor's emphasis on the knowledge product to be sufficiently persuasive so that audiences will accept the knowledge. This seemed to have contributed to the students' focus on justifications based on evidence. The whole-class discussion at the end of the second phase and the students' exchange of constructive feedback on how to refine the original plans designed in groups also contributed to increasing the persuasiveness of the knowledge products and the validity of the plans. For example, one group planned to explore "how changes in human activities caused by the spread of COVID-19 influenced the environment," and the students in other groups suggested feedback such as, "I think a logical explanation would be important because the spread of COVID-19 virus is still ongoing" and "I think that "the environment' is way too broad for an investigation." The feedback to the group supported the group to refine their justification process, specifically to concretize the subject and consider whether tentative knowledge claims can be justified by the data that the students planned to use. Thus, with the emphasis on persuasiveness, the explication to audiences, who are the subjects to be persuaded, allowed the classroom participants to co-develop plans for knowledge construction to be scientifically meaningful. 
In most of the groups, the construction of mechanistic explanations was also facilitated when they planned to construct personalized knowledge for the audiences. Jen and Ryu's group was one of these groups. They posed the following two research questions: (a) Why do people respond differently to coffee? (b) How can people obtain the effects that they want from caffeine without side effects? Then, the students formulated hypotheses related to the items listed under "Exploration and suggestion of alternatives" in the table of contents. In this way, they attempted to construct mechanistic explanations of how the external factors that they specified as features of the audience changed their physiological status. Then, they planned to observe their own differing responses to caffeine and connect the mechanistic explanation that they constructed to explain the observations and produce personalized suggestions. Thus, the mechanistic explanation was necessary to provide personalized knowledge to the audience.

However, significant changes were made in Jen and Ryu's activity in the third phase, which showed limitations in supporting the students' shaping of scientifically meaningful knowledge construction. Because the students had difficulty experimentally exploring all the physiological mechanisms caused by external factors, they adopted a literature review as a method of knowledge construction. However, Jen and Ryu could not find information on the mechanism to which they could anchor an explanation of the phenomena that they observed. Therefore, their final report included descriptions of phenomena that they observed or found in the literature and separate explanations for the many mediating factors that can lead to different physiological changes. Subsequently, in another final knowledge product titled "prescriptions" (Fig. 5), the students described observable physiological phenomena and included general suggestions on how to prevent the side effects of consuming coffee. The suggestions were supported by general knowledge about how caffeine works in the human body, but they were not connected to each person's symptoms. Thus, the knowledge claim was justified by including the related information from authoritative sources in the knowledge product without the reasoning that links personal physiological characteristics to personalized methods of caffeine consumption. One reason for such a limitation in constructing evidence-based mechanistic explanations of phenomena could be a lack of consideration of available resources for the activity when creating audiences and specifying the phenomena to make sense of. The students may have aimed to construct a mechanistic explanation that was too broad because they aimed to produce knowledge that could directly lead to a practical utility, which often takes considerable resources and time, even for scientists.

Another limitation on supporting the students' shaping of scientifically meaningful knowledge construction was that the construction of mechanistic explanations was not necessary to achieve epistemic goals in many of the groups. Han and Jeong's group is a representative case. In this group, an audience was constructed as "a lecturer who comes into contact with many students in a small classroom" (Fig. 6), and the subject to figure out was determined to be the most efficient method for hand sanitizing. The epistemic goal focused on practical utility as specified in the "concerns and problems that the audience wants to solve" section. There, it was explained that the lecturer wanted to determine the type and amount of sanitizer most effective for hand sanitizing. According to the epistemic goal, the students intended to construct knowledge to find the most effective choices, as justified by the experimental data. They specified different sanitizing methods as alternative hypotheses and evaluated the alternatives experimentally. Although the sources of knowledge varied between empirical experiments and the literature, the final knowledge product included only a conclusive answer to the audience's concerns and photos of their experimental results (Fig. 7). When asked why they included only the photos in their final product, they answered that they thought that the audience was "too busy" to read the full 
[Translation]

처방전

\begin{tabular}{|c|c|c|c|c|}
\hline 요양 기관번호 & \multicolumn{4}{|c|}{$500-7114$} \\
\hline 교부번호 & \multicolumn{4}{|c|}{ 2020년 6월 12일 - 제 12 호 } \\
\hline 한자 & 성명 & Ryu & 익변 & 201905020 \\
\hline \multirow{3}{*}{ 의료기관 } & 명징 & \multicolumn{3}{|c|}{ OO Hospital } \\
\hline & 전화번호 & $000 \cdot 000-000$ & FAX번호 & $000-000-000$ \\
\hline & e-mail & \multicolumn{3}{|c|}{ ryu@ryu.com } \\
\hline 질병분류명칭 & $\begin{array}{c}\text { 작용은 없고 } \\
\text { 부작용은 있는 } \\
\text { 옵쓸 병 }\end{array}$ & $\begin{array}{c}\text { 처방의료인의 } \\
\text { 성명 }\end{array}$ & \multicolumn{2}{|c|}{000} \\
\hline 면허종별 & 재학 & 면허번호 & \multicolumn{2}{|c|}{$201905022-24$} \\
\hline
\end{tabular}

완자의 요구가 있을 태에는 질병분류명칭을 기재하지 아니합니다.

이 환자는 커피률 마셔도 효과를 보지 못하나 3-4잔 이상 마셨을 경우는 두근거림이나 데스꺼움 등의 증상이 나타난다. 따라서 이 환자에 대한 처방은 작용보다는 부작용을 막는 데에 초점을 두며 그 처방은 이러하다.

첫째, 커띠률 3 잔 이상 마시지 말 것. 사람마다 카페인이 몸에서 분해되는 정도가 다르므 로 자신의 분해정도에 맞춰 섭취해야 한다.

둘째, 커피를 3 잔 이상 마셔야하는 경우 3 잔 이후로는 커미 대신 차를 마시도록 노릭한 다. 차는 커띠보다 카페인의 작용이 느리고 카페인의 홍분 작용을 억제시키는 성분이 함께 있어 카페인을 과잉 섭쉬하였을 때 나타나는 부작용을 방지해주는 효과가 있다.

\section{Prescription}

\begin{tabular}{|c|c|c|c|c|c|}
\hline Nursing home \# & \multicolumn{5}{|c|}{$500-7114$} \\
\hline Prescription \# & \multicolumn{5}{|c|}{ 2020년 6월 12일 - 제 12 호 } \\
\hline Patient & Name & & yu & $\begin{array}{l}\text { Student } \\
\text { ID }\end{array}$ & 201905020 \\
\hline \multirow{3}{*}{ Hospital } & Name & \multicolumn{4}{|c|}{ OO Hospital } \\
\hline & Phone & 000 & $00-000$ & $\mathrm{FAX} \#$ & $000-000-000$ \\
\hline & e-mail & \multicolumn{4}{|c|}{ ryu@ryu.com } \\
\hline Disease & \multicolumn{2}{|c|}{$\begin{array}{l}\text { A nasty disease with } \\
\text { no pros and only } \\
\text { side effects }\end{array}$} & $\begin{array}{c}\text { Prescribin } \\
\mathrm{g} \text { doctor } \\
\text { name }\end{array}$ & \multicolumn{2}{|c|}{000 (인) } \\
\hline License & \multicolumn{2}{|c|}{$\begin{array}{c}\text { Undergraduate } \\
\text { student }\end{array}$} & License \# & \multicolumn{2}{|c|}{$201905022-24$} \\
\hline
\end{tabular}

- Disease name does not have to be written when the patient requests it.

This patient does not experience any effect after drinking coffee, but if she drinks more than 3-4 cups. she experiences symptoms such as a pounding heart or nausea. Therefore, the prescription for this patient focuses on preventing side effects rather than lincreasingl effects, and the following is the specific prescriptions.

First. do not drink more than 3 cups of coffee. Each person should take caffeine according to his or her own level of caffeine decomposition because it differs in degree from person to person.

Second. if you have to drink more than 3 cups of coffee. try to drink tea instead of coffee after 3 cups. Tea has a slower caffeine effect than coffee and contains ingredients that suppress the excitatory effect of caffeine. which helps prevent the side effects of excessive caffeine intake.

Fig. 5 Part of the suggestions in the form of a prescription

\begin{tabular}{|c|c|}
\hline & [Translation] \\
\hline 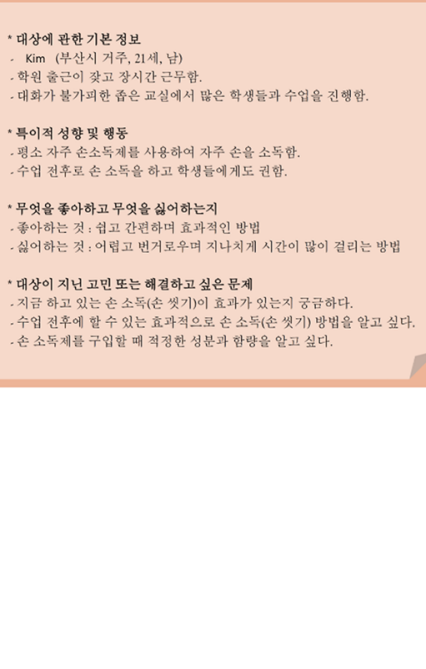 & $\begin{array}{l}\text { A lecturer who works at a private institution } \\
\text { * basic information about the persona } \\
\text { - Kim (lives in Busan, } 21 \text { years old, male) } \\
\text { - gives frequent and long lectures } \\
\text { - holds classes with many students in a small classroom } \\
\text { where conversation is inevitable } \\
\text { * Unique characteristics and behaviours } \\
\text { - frequently uses hand sanitizer } \\
\text { - uses hand sanitizer before and after class and recommends } \\
\text { sanitizers to students } \\
\text { * Likes and dislikes } \\
\text { - likes: easy and effective methods } \\
\text { - dislikes: difficult, cumbersome, and time-consuming } \\
\text { methods } \\
\text { * Concerns and problems that the persona wants to solve } \\
\text { - wonder whether the current hand sanitization method, } \\
\text { which is to wash his hands with water, is effective } \\
\text { - wants to know effective hand-washing methods that he } \\
\text { can use before and after class } \\
\text { - wants to know the proper types of and amounts of } \\
\text { ingredients in hand sanitizers }\end{array}$ \\
\hline
\end{tabular}

Fig. 6 Description of audiences created by Han and Jeong 


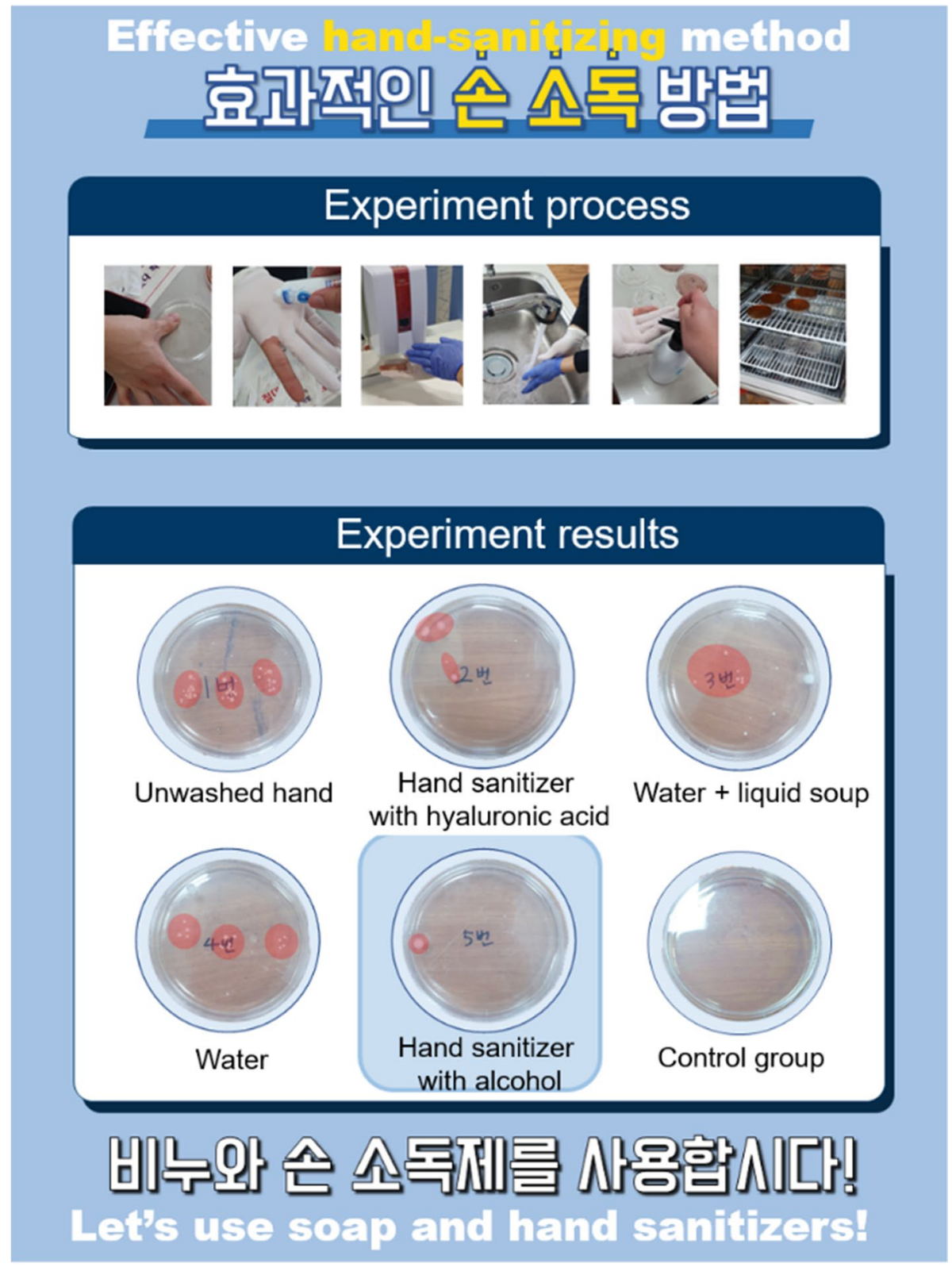

Fig. 7 The final knowledge product of Han and Jeong's group

explanation. This omission of a mechanistic explanation in the final knowledge product indicates students' epistemic idea that describing observations of phenomena can suffice to persuade the audience of the students' argument. This seemed to be the reason for focusing on describing phenomena in the groups with the epistemic goals of producing knowledge for practical usage.

In some groups with the goal of figuring out what phenomena occurred also did not produce mechanistic explanations. A representative case is the group that explored "how changes in 
human activities caused by the spread of COVID-19 influenced the environment." The students in this group presumed a causal link between the change in air quality and COVID-19, and they focused on identifying changes in air quality in South Korea by analyzing data on the amount of fine dust reported by official websites. They drew and compared graphs that showed changes in the amount of fine dust in 2018 and 2019 and reported that the figure drastically decreased in 2020 (as shown in the third slide of the final product, Fig. 8). Thus, in some cases, students' knowledge construction was more focused on the depiction of the phenomena that occurred when the reasons for the phenomena were presumed based on the students' common knowledge.

\section{Conclusion and Discussion}

\section{Elicitation of Audiences to Facilitate Students' Epistemic Agency}

This study explored how the establishment of audiences can support students' shaping of knowledge construction that is meaningful to them and scientifically meaningful when students are invited to create audiences for knowledge that the students will

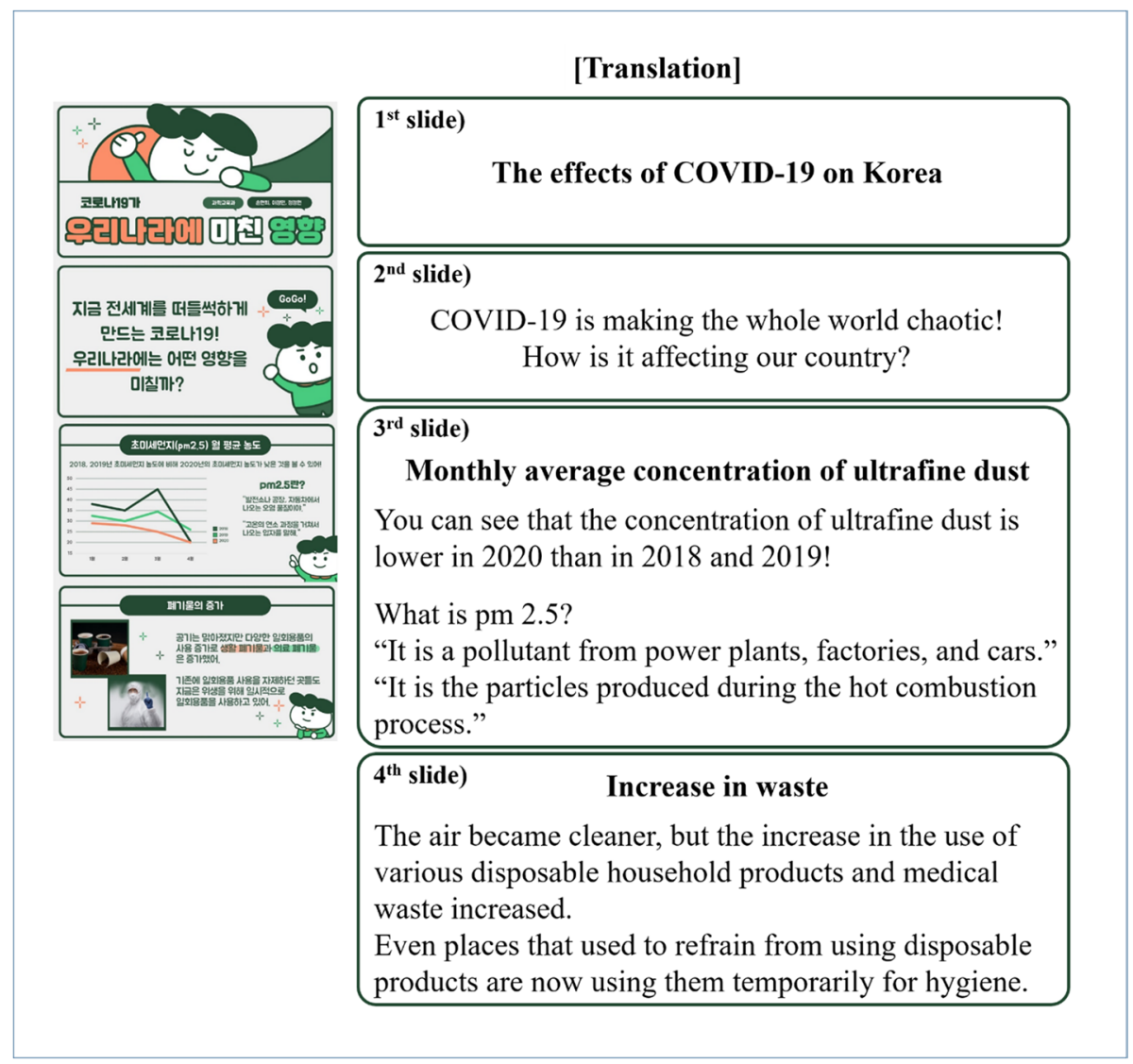

Fig. 8 Front part of the final knowledge product by Chung, Min, and Sue 
construct. The findings of this study corroborate previous studies (Ko \& Krist, 2019; Miller et al., 2018; Reiser et al., 2017) by showing that opening the curricula for students to engage in while shaping their knowledge construction can facilitate students' epistemic agency in the science classroom. The findings further suggest one potential instructional strategy that supports students' positioning as epistemic agents in the sense of who establishes epistemic goals and pursues them in the science classroom rather than students' engagement in knowledge construction trajectories already arranged by teachers.

The student-created audiences usually reflected themselves or their acquaintances and described holding uncertainties that the students actually had. As the students added descriptions of why their audiences wanted certain knowledge, epistemic goals other than sense-making emerged and created audiences served as the central axis in the students' subsequent shaping of knowledge construction activities. Based on the audiences and epistemic goals, the students made decisions on how personalized the knowledge products should be and what knowledge should be used to make their suggestions to the audience the most persuasive. These decisions were reflected in the nature of the scientific knowledge and in the process of the justification aspects in the students' plans for knowledge construction. In addition, the explicated epistemic goals that the students set allowed the classroom participants to share constructive feedback and improve on the original plans to increase the validity of the subsequent knowledge construction processes.

Supporting students' epistemic agency entails more than engagement in knowledge construction, for which trajectories are already presumed by teachers (Reiser et al., 2017). However, students still need criteria on which to rely to evaluate and adjust their trajectories of knowledge construction when they participate in shaping their activities. The findings of this study provide empirical evidence that student-created audiences can work as criteria that students can rely on to shape their own and others' knowledge construction process in the science classroom. This indicates the potential of the instructional strategy of inviting students to set audiences for knowledge for their knowledge construction to support their epistemic agency.

\section{Supporting Students' Shaping of Knowledge Construction Activities That Are Meaningful to the Scientific Community and the Classroom Community}

Inviting students to help design their knowledge construction is not an easy choice for instructors because of tensions between designing curricula that appropriate epistemic features of scientific practices and prioritizing students' ideas (Stroupe et al., 2018). The findings of this study demonstrated that inviting students to create an audience for knowledge first and to then design their subsequent knowledge construction processes can support students' shaping of knowledge construction that is meaningful to themselves. The audiences that the students created reflected features of themselves or the people that they encountered in their daily lives, and the students designed procedures to construct knowledge for the created audiences.

Regarding whether students' establishment of audiences can support their shaping of knowledge construction that is meaningful to the scientific community, the answer is not a simple yes or no. The students' practices were scientifically meaningful in that they produced knowledge based on analyses of data that they collected from various sources, such as empirical experiments and observations. Some groups also attempted to explore 
the mechanisms underlying the phenomena. These results indicate that the introduction to scientific practices, such as modeling and argumentation, in the course prior to the activity and the emphasis put on persuasiveness was effective for the students to frame the classroom activities as sense-making activities. This finding corroborates that support for students in adapting scientific practices can support students' epistemic agency in the science classroom (González-Howard \& McNeill, 2020).

However, the students' original plans to construct mechanistic explanations were not successfully enacted, and the students did not include this mechanistic explanation in their final products in most of the cases. Thus, the justifications of knowledge that the students produced were not robust. For example, in Jen and Ryu's case, the students aimed to produce the mechanistic explanation underlying their phenomenological observations, but they lacked the resources and time needed to conduct such additional investigations. Although the contexts can differ, designing research that considers affordances and constraints in constructing valid knowledge claims is a significant part of scientists' epistemic practices (Pickering, 1995). How can we interpret such student practices? The students might have aimed to construct a mechanistic explanation that was too broad because they aimed to produce knowledge that could lead directly to practical utility. This often takes considerable resources and time, even for scientists. This result indicates that an instructional strategy is needed to support students in managing such structural affordances and constraints in designing epistemic goals and knowledge construction procedures. Then, students can maintain the enactment of scientifically meaningful epistemic ideas in their activities.

Meanwhile, there were groups that did not need to produce mechanistic explanations to achieve their epistemic goals. Although the construction of a mechanistic explanation of the natural world is a main goal in many scientific communities, describing the natural phenomena has value in many scientific fields. Furthermore, the identification of phenomena can be a remarkable achievement. For example, reporting previously unknown or unique natural phenomena holds scientific value. In this sense, although valid evidence-based mechanistic reasoning was not constructed to explain the phenomena, the students' construction of a data-based explanation of changes in the air quality could be described as valuable work conducted by epistemic agents because they wanted to figure out through their investigation whether the air quality truly improved after the spread of COVID-19. Their knowledge construction was the process by which they understood the natural world. Considering this point, this study suggests that to support students in shaping knowledge construction that is meaningful even to the scientific community, the focus needs to be on the design and enactment of valid but possibly various methods to construct evidence-based explanations of the natural world so that students' uncertainties about the natural world can be resolved. Further discussions are needed to develop our view of the relationship between students' epistemic agency and the goal of "sense-making," which is described as the construction of mechanistic explanations that can make sense of the natural world in science education.

The explication of epistemic goals by creating an audience for knowledge was proposed by this study as one strategy to support students as they relate to their own scientifically meaningful knowledge construction in the science classroom. It is necessary to empirically examine the instructional strategies suggested to improve the support of students' epistemic agency. In addition, instructors have other concerns, such as the extensive time load needed to elicit and develop students' ideas when instructors aim to support students' epistemic agency. Additionally, it could be overwhelming for some students to begin knowledge construction from contriving audiences for knowledge and designing research methods. In 
this case, reducing the features of the entire activity that are opened up to students can be useful. Further studies are needed to develop methods of addressing instructors' concerns about inviting students to shape knowledge construction activities. Considering that these concerns are the main reason that many instructors hesitate to open their curricula to students, further studies are needed about instructional strategies to relieve these concerns and to support students' epistemic agency in the science classroom.

\section{Appendix}

Appendix 1 Final codes for the students' epistemic ideas

\begin{tabular}{ll}
\hline Epistemic aspects & Codes \\
\hline Audience for knowledge & a) Audiences with a description of the knowledge they want to know \\
& b) Audiences with a description of why and what knowledge they want to know \\
c) Audiences with a description of why and what knowledge they want to know \\
and the features they have that can be mediating factors on the explored \\
phenomena \\
d) Description of phenomena \\
Sature of knowledge & e) Mechanistic explanation of the phenomena \\
f) Explanation of mediating factors on the phenomena \\
g) Empirical experiments \\
h) Literature (previous studies) \\
$\begin{array}{ll}\text { i) Data reported by official websites } \\
\text { j) News articles } \\
\text { k) Observation of the phenomena } \\
\text { 1) A knowledge claim can be justified by our interpretation of the data } \\
\text { m) Our knowledge product includes the knowledge from authoritative sources } \\
\text { n) A knowledge claim does not have to be supported by evidence } \\
\text { o) A knowledge claim can be justified by including relevant information from } \\
\text { authoritative sources in our knowledge product } \\
\text { p) A knowledge claim can be justified by including the data in our knowledge } \\
\text { product }\end{array}$
\end{tabular}

Appendix 2 Final codes for the epistemic goals

\begin{tabular}{ll}
\hline Codes & Meaning \\
\hline q) To make sense of phenomena & $\begin{array}{c}\text { Aim to construct explanations that can make sense of natural } \\
\text { phenomena }\end{array}$ \\
r) For practical utility & $\begin{array}{c}\text { Aim to construct knowledge that can be used for making } \\
\text { decisions regarding socio-scientific issues for personal } \\
\text { benefit in daily life }\end{array}$ \\
s) To make a public service advertisement & $\begin{array}{c}\text { Aim to produce knowledge that can support claims in public } \\
\text { service advertisements that argue for changes in public } \\
\text { attitudes and behaviors toward socio-scientific issues }\end{array}$ \\
&
\end{tabular}


Funding This work was supported by the Ministry of Education of the Republic of Korea and the National Research Foundation of Korea (NRF-2020S1A5B5A16083113).

\section{References}

Berland, L. K., Schwarz, C. V., Krist, C., Kenyon, L., Lo, A. S., \& Reiser, B. J. (2016). Epistemologies in practice: Making scientific practices meaningful for students. Journal of Research in Science Teaching, 53(7), 1082-1112.

Duschl, R. A., \& Grandy, R. E. (2008). Teaching scientific inquiry Recommendations for research and implementation. Sense Publishers.

Engeström, Y. (1987). Learning by expanding: An activity theoretical approach to developmental research. Helsinki, Finland: OrientaKonsultit.

Ford, M. J. (2015). Educational implications of choosing "practice" to describe science in the next generation science standards. Science Education, 99(6), 1041-1048.

González-Howard, M., \& McNeill, K. L. (2020). Acting with epistemic agency: Characterizing student critique during argumentation discussions. Science Education, 104(6), 953-982.

Hammer, D., \& Elby, A. (2002). On the form of a personal epistemology. In B. K. Hofer \& P. R. Pintrich (Eds.), Personal epistemology: The psychology of beliefs about knowledge and knowing (pp. 169-190). Routledge.

Haugen, A. (2002). Women who smoke: Are women more susceptible to tobacco-induced lung cancer? Carcinogenesis, 23(2), 227-229.

Holland, D., Lachicotte, W., Skinner, D., \& Cain, C. (1998). Identity and agency in cultural worlds. Harvard University Press.

Ko, M. M., \& Krist, C. (2019). Opening up curricula to redistribute epistemic agency: A framework for supporting science teaching. Science Education, 103, 979-1010.

Merriam, S. B. (1998). Qualitative research and case study applications in education. Jossey-Bass Publishers.

Miller, E., Manz, E., Russ, R., Stroupe, D., \& Berland, L. (2018). Addressing the epistemic elephant in the room: Epistemic agency and the next generation science standrads. Journal of Research in Science Teaching, 55, 1053-1075.

Myers, G. (2003). Discourse studies of scientific popularization: Questioning the boundaries. Discourse Studies, 5(2), 265-279.

National Research Council (2012). A framework for K-12 science education: Practices, crosscutting concepts, and core ideas. National Academies Press

Pickering, A. (1995). The mangle of practice: Time, agency, and science. University of Chicago Press.

Reiser, B. J., Novak, M., \& McGill, T. A. (2017). Coherence from the students' perspectives: Why the vision of the framework from K-12 science requires more than simply "combining" three dimensions of science learning. Paper commissioned for the Board on Science Education Workshop "Instructional Materials for the Next Generation Science Standards."

Sandoval, W. A. (2005). Understanding students' practical epistemologies and their influence on learning through inquiry. Science Education, 89(4), 634-656.

Stroupe, D., Caballero, M. D., \& White, P. (2018). Fostering students' epistemic agency through the co-configuration of moth research. Science Education, 20(18), 1-25.

Publisher's Note Springer Nature remains neutral with regard to jurisdictional claims in published maps and institutional affiliations. 